\title{
NATIONAL ADDICTION-SPECIFIC INSTITUTIONAL INFRASTRUCTURE - FUNDAMENTAL PREREQUISITE FOR SUCCESSFUL IMPLEMENTATION OF SPECIALIZED ACADEMIC DEGREE STUDY PROGRAMMES: A CASE STUDY IN HISTORICAL PERSPECTIVE
}

\author{
Michal Miovský1, Anna Vondrová1, Roger Peters², Beatrice Kathungu³, Amalie Lososová1 \\ ${ }^{1}$ Department of Addictology, First Faculty of Medicine, Charles University and General University Hospital in Prague, Prague, Czech Republic \\ 2UTC/UPC Coordinating Centre, University of South Florida, Tampa, Florida, USA \\ ${ }^{3}$ Department of Psychology, Kenyatta University, Nairobi, Kenya
}

\begin{abstract}
SUMMARY
Objective: Human resources are crucial for addiction treatment and prevention services, as well as for science and research. The aim of this historical case study is to explain and demonstrate the role of specialized university academic degree study programmes in addictions in the context of a national institutional infrastructure. This specific group of very highly specialized academic programmes represents the highest level of professional development and is producing a totally new generation of addiction specialists with a very distinctive professional identity.

Methods: The study protocol is based on a case study research design and the case is defined as the historical development of addiction specialized institutions closely related to self-help, prevention, and treatment activities on the historical territory of the Czech Republic. We identified relevant historical sources related to establishing and/or running activities or institutions according to the categories specified in our concept of the national institutional infrastructure. All the materials and sources that were collected were sorted according to a timeline and categories of institutions and we systematically determined the first recorded activity/institution in each particular category. For this simple sorting system we used open and selected coding according to Grounded Theory.

Results: The public health model developed by Thomas Babor recognizes six different structural mechanisms to support university-based programmes in addiction studies: specialized journals, research centres, professional societies, specialized libraries and documentation centres, training and education programmes and institutions, and funding agencies. We attempted to redefine the concept of addiction studies within the broader context of the addiction field and added three additional mechanisms of support: public interest groups, self-help groups, and service providers. Using a historical case study in the Czech Republic, we demonstrate the potential for a broader context and interaction between these support mechanisms and academic institutions hosting academic programmes in addiction studies.

Conclusion: The process of establishing integrated addiction studies programmes at Charles University in the Czech Republic had its origins in, and support from, various national institutions and professional organizations. This allowed the university to develop academic programmes at the bachelor's, master's, and Ph.D. levels. The availability of career opportunities for advanced-level addiction professionals in the Czech Republic was also a critically important factor in developing sustainable academic programmes in addiction studies. Our experience is that the creation of successful and sustainable academic programmes for addiction professionals is difficult to achieve without broad infrastructure support, national advocacy efforts, and legislative change at the national level.
\end{abstract}

Key words: academic degree study programmes, specialized addiction programmes, public health, institutional infrastructure, implementation process

Address for correspondence: M. Miovský, Charles University and General University Hospital in Prague, First Faculty of Medicine, Department of Addictology, Apolinářská 4, 12800 Prague 2, Czech Republic. E-mail: michal.miovsky@lf1.cuni.cz

https://doi.org/10.21101/cejph.a5980

\section{INTRODUCTION}

We are witnessing exponential growth in addiction-specific academic degree programmes at different universities around the world. This rapid expansion is due in part to the ascent of addiction prevention and treatment programmes in recent decades.
The roots of university-based addiction studies programmes were established 150 years ago, when the first real professional societies (e.g. the American Association for the Study and Cure of Inebriety in 1870) and journals (e.g. the British Journal of Inebriety in 1884) were established (1). The addiction field still remains generally unrecognized as a unique and independent scientific field and 
discipline, despite the fact that it has all the necessary features, such as a specific theory, terminology, concepts, and methods.

In the past, the addiction specialization has been supported by advances in clinical practice, and a significant amount of research conducted by the dominant disciplines of neurology, psychiatry, psychology, and social work. On the other hand, it is possible to find some of the first original concepts and definitions of addiction as a freestanding, unique, and independent field based on interdisciplinary approaches from the mental health and public health fields $(2,3)$. This process of developing a distinctive and independent infrastructure to support academic training in addiction studies has been described by Babor et al. (1), and involves considerable maturation beyond the origins of addiction services that emerged from historical self-help initiatives and public awareness initiatives.

From a global perspective, Babor et al. (1) recognized six different types of structural mechanisms to support university-based programmes in addiction studies: specialized journals, research centres, professional societies, specialized libraries and documentation centres, training and education programmes and institutions, and funding agencies. If we put the concept of addiction studies into a broader context defining the entire addiction field, three more categories can be recognized: public interest groups, selfhelp groups, and initiatives and service providers (Fig. 1).

Babor's public health perspective defines the institutional infrastructure as a product of the complex process of the development of the entire addiction field, but it concerns especially the first two categories (A and B in Fig. 1) of institutions that change this perspective and play the key role. Service providers, patient initiatives, and self-help groups justify the existence of the field. They are the reason for developing and supporting each of the other institutional components and the network as a whole. Only real people at risk of, and affected by, Substance Use Disorders (SUD) and broader public interests and needs related to SUD can be the reason for the establishment and development of the addiction field and the entire institutional infrastructure. The addiction field does not represent only some kind of specialization that is an alternative to the original background of these specialists (medicine, psychology, social work, etc.), it is one where we can recognize many different aspects of these specializations (2). The addiction field has its own core professional background based on an interdisciplinary perspective on addictions with its own specific terminology, theory, and methods (Fig. 1). It constitutes a new emerging group of addiction professionals with their own professional identity and self-definition (4).

Currently, there may be almost 500 academic degree programmes around the world that specialize in addiction. The types of programmes are very different; some of them are courses in other major programmes, or certificates, and yet most of them are awarded a degree. In Europe, 34 original programmes at 25 universities have been identified (5). Most of the programmes involved a master's level (44\%), bachelor's programmes accounted for $15 \%$, and only $4 \%$ were postgraduate studies (awarded a Ph.D. degree). A slightly different situation was recorded in the United Kingdom, where, because of its different education system, it is possible to identify "Associate" academic programmes. The authors also recognized that half of the programmes include clinical practice as a compulsory part of the degree requirements (5).

A large number of addiction study programmes are available in North America. We can find almost 400 different programmes across the USA, offered at 333 universities. 300 of these programmes are degree programmes. Again, the education system in the USA has its own specific features, and there are also variations from state to state, so we can find degree programmes on the associate level (the most widespread form, covering 53\% of all the programmes that were identified), standard bachelor's degree alternatives ( $16 \%$ of the programmes), master's programmes (18\%), and less than $2 \%$ that are doctorate-level programmes only (6). Many of the academic programmes also offer certificates and diplomas. Two states provide no addiction study programmes. Here we can observe a trend towards offering mostly clinicallyoriented training rather than training oriented towards research or drug policy.

The situation in other parts of the world is very diverse. We can find 22 programmes in Australia and 21 programmes in New Zealand, but only three programmes in Latin America, four programmes in Asia, and eight different programmes in Africa. This data is based on research using a few pre-defined key words (and so the numbers may be much greater) and will be published soon. Only three universities in the world offer comprehensive

\begin{tabular}{|l|l|l|}
\hline \multicolumn{3}{|c|}{$\begin{array}{c}\text { Addiction discipline/field } \\
\text { (theories, methods, and terminology) }\end{array}$} \\
\hline & & \\
\hline $\begin{array}{l}\text { (A) Self-help and patient } \\
\text { activities }\end{array}$ & (B) Service providers & (C) Addiction studies \\
\hline (A1) Self-help groups & (B1) Prevention services & (C1) Specialized journals \\
\hline (A2) Recovery groups & $\begin{array}{l}\text { (B2) Treatment and rehabilitation } \\
\text { services }\end{array}$ & (C2) Research centres \\
\hline (A3) Natural recovery & $\begin{array}{l}\text { (B3) Harm reduction and risk } \\
\text { reduction services and activities }\end{array}$ & (C3) Professional societies \\
\hline (A4) Patient initiatives & & $\begin{array}{l}\text { (C4) Specialized libraries and } \\
\text { documentation centres }\end{array}$ \\
\hline (A5) Public interest groups & & $\begin{array}{l}\text { (C5) Training and education } \\
\text { programmes and institutions }\end{array}$ \\
\hline & & $\begin{array}{l}\text { (C6) Funding agencies and policy } \\
\text { makers }\end{array}$ \\
\hline
\end{tabular}

Fig. 1. Key disciplinary components in the field of addiction. 
education in the specialized field of addiction study programmes (Czech Republic, Europe; New York State, USA; Commonwealth of Dominica, Latin America), which means all three university levels (bachelor's, master's, and doctoral) $(5,6)$.

The systematic approach of the International Society of Substance Use Professionals (ISSUP) and International Consortium of Universities on Drug Demand Reduction (ICUDDR) has facilitated discussion about the potential and real roles of universities as one of the key stakeholders and the potential for further development. The Universal Treatment Curriculum (UTC) and Universal Prevention Curriculum (UPC) bring a revolutionary perspective on addiction education and training activities, not only because of the discussion about quality and sustainability in service provision and developing the workforce, but also in terms of the compatibility and transferability of different kinds of education and training programmes and issues related to the implementation process and its impact on everyday praxis and real drug policy. The process of the adaptation and implementation of university curricula means a systematic and evaluated process integrating the UTC/UPC into a real academic degree university study programme (bachelor's, master's, Ph.D., etc.). In practice, it means covering preparatory work, work with an academic team, accreditation according to national rules and standards and requirements, and producing graduates with formally accepted education and training dedicated to the issue of addiction and provided by a particular university; integrating real clinical training/praxis (internship) components and matching learning outcomes with the "real-world" labour market and the needs of employers or potential employers; and linking the real university study programme with the existing institutional infrastructure (e.g., national societies, employers, journals, policymakers, legislation, etc.).

The aim of this case study is to explain the role of specialized university academic degree study programmes in addictions in the context of a national institutional infrastructure. This specific group of very highly specialized academic programmes represents the highest level of professional development and is producing a totally new generation of addiction specialists with a very distinctive professional identity.

\section{Methodological Framework and Database}

The methodological framework is based on a case study research design and the case is defined as a historical development of institutions specializing in addiction that are closely related to self-help, prevention, and treatment activities on the historical territory of the Czech Republic. The data collection phase was conducted using the key words alcohol and alcoholism, spirit, self-help, treatment, prevention, education and training, substance use, and addiction. We tried to identify every relevant historical source related to establishing and/or running activities or institutions according to the categories specified in our concept of the national institutional infrastructure (Fig. 1). All the materials and sources that were collected were sorted according to a timeline and categories of institutions and we systematically determined the first recorded activity/institution in each particular category. For this simple sorting system we used open and selected coding according to the Grounded Theory of Glaser and Strauss (8) in an upgraded version published by Strauss and Corbin (9). After matching all the sources and creating institutional categories, we constructed a timeline inspired by the sorting system that was developed, presented in the first part of this paper (Fig. 1), and described all the key historical milestones relevant to building the specialized national institutional infrastructure in the addiction field. For this process we used very simple analytical tools based on creating categories and a comparative process inspired by Miles and Huberman (10) and qualitative content analysis (11). The project was closely linked to our former work on historical analysis of origins that contributed to the modern concept of addiction studies, created and systematically developed in Prague $(3,12)$.

\section{Historical Development and Context of Central European Infrastructure: Public Health Perspective}

Historically, Central Europe has many different specific features with regard to the development of addiction institutions, with the expectable gradient in terms of order and exponential growth. In the Austro-Hungarian Monarchy, encompassing all the Central European countries, the 19th century was unexpectedly characterized by the relatively high public awareness of alcoholrelated problems.

\section{Emergence of Addiction as an Issue: the First Self-help Activi- ties and Public Health Measures}

The most natural response to increasing impacts and troubles related to substance use in every society is the development of spontaneous initiatives by many different interest groups and the emergence of the first self-help efforts and activities. In Central Europe the first self-help initiatives can be traced back to the early 1840 s (3), with the first prevention initiatives soon following $(13,14)$. In Moravia, the first public interest groups aimed at "fighting alcohol" and developing dedicated activities date back to the 1900s. They were initiated and established by Josef Hybeš, a politician who became the first official chair of the temperance movement (15). In 1905, the National Fellowship against Alcoholism was established in Prague. In general, this historical line helped to form a totally new profile of self-help and quasi-selfhelp initiatives in Central Europe (16). It was typical that the local professional services and self-help groups co-existed peacefully and tolerated each other. Later, in 1948, this made it possible for both of these strands to combine in the emerging treatment programme provided by the Apolinar facility. Interestingly, the oldest continuously existing socio-therapeutic club, KLUS (Club of People Seeking Sobriety) came into existence, both practically and formally, even six months earlier (on 5 February 1948) than the specialist inpatient treatment programme (7 October 1948) affiliated with the Psychiatric Department of the Faculty of General Medicine of Charles University (17)

KLUS was inspired by the concept of self-help and ideas embraced by the US Alcoholics Anonymous (AA). Their meetings were attended by patients in recovery, those who were currently undergoing treatment, family members and, of course, a therapist or a medical doctor (16). Unfortunately, just a few days later, on 25 February 1948, the Communist ideology prevailed in what was then Czechoslovakia, and it did not accept the spiritual elements contained in the AA 12-Step programme. In practice, this made it impossible for AA to operate officially and openly in the country until the 1989 Velvet Revolution. In December 1989 the first small group convened at the Apolinar centre to resume 
the local operation of AA. In 1974, as part of the activities developed by the Apolinar Cabinet for the Prevention of Alcohol and Other Toxicomanias, an experimental musical programme was introduced. After 1989, a wide range of self-help activities became established. In addition to AA, Narcotics Anonymous (NA) also began to provide their services. There were efforts to scale up and facilitate the development of this segment by means of a number of projects (18), the levels of sustainability of which varied, unfortunately. The establishment of the first ever union of patients representing the interests of patients in addiction treatment and recovery in 2017 represented a great achievement. This was a significant step, given the important position of these structures in terms of the development of the health insurers' services and policies, where patients' associations can play an influential role.

\section{Emergence of the First Specialized Residential Facilities for Alcohol Treatment}

Several decades after the establishment of the first self-help groups, the first professional residential treatment programmes, including additional abstinence-oriented support organizations and structures, also began to emerge. The first alcohol institution in what is now the Czech Republic was opened in Velké Kunčice. The main driving force and leading figure behind the establishment of the Cross Association for the Establishment and Maintenance of an Alcohol Institution in Moravia was Father Bedřich Konařík (19). On 27 December 1911 the Board of the Cross Association received a memorandum authorizing the commencement of its activities. After the Great War and the proclamation of an independent Czechoslovakia in 1918 the idea of establishing and operating a treatment institution assisting individuals dependent on alcohol was revisited (20). The Ministry of Public Health and Physical Education had been considering the idea since 1919. Initially, it was proposed that three separate public treatment facilities should be established - for men, women, and incurable alcoholics. The Tuchlov institution was established by an edict issued by the Ministry of Public Health and Physical Education on 31 December 1923. The main co-founders were Břetislav Foustka and Bedřich Konařík. Other distinguished personalities who helped establish the treatment facility included Hynek Fügner and doctor Jan Šimsa (the first attending physician there). In addition to being appointed as the manager of the treatment institution, Father Bedřich Konařík also worked there as an educator; the first patient entered treatment on 1 November 1923.

The first treatment and prevention activities in what is now the Czech Republic drew and built on foreign experience and knowledge, especially the Swiss, German, English, and Swedish models. Major sources of inspiration included the Swedish treatment facility Eolshäll or the Swiss approach pursued by Bosshard in the Ellikon facility. These two treatment facilities and the treatment model applied in the north of Germany were the main representatives of the "open-door" approach emphasizing the voluntary aspect of treatment and mutual trust between the therapist and the patient, as well as expecting the patients to assume some responsibility for their attitude to treatment and their behaviour. While also embracing the voluntary aspect of treatment, other treatment institutions, particularly those based in England, applied what was referred to as a "closed-door" approach, associated with significant restrictions and obligations being imposed on patients (19).

The operation of both of the aforementioned treatment facilities was interrupted by the world wars. Thus, the Apolinar centre (currently the Department of Addictology) remains the oldest residential treatment facility existing continually until today. The leading figure in the post-war development of the entire field and the founder of the Apolinar facility was Jaroslav Skála. It was Skála's approach to alcohol treatment (21) that provided a template and model for the entire network of residential facilities that came into existence between the 1960s and 1980s in what was then Czechoslovakia. The post-1989 years then saw a dramatic development of therapeutic communities and aftercare programmes, in particular, which was due to significant support for the growth of the non-profit sector. The 1970s and 1980s witnessed a dynamic development of outpatient alcohol treatment, with even a state-sponsored network of outpatient clinics, numbering some 200 facilities at the time of the greatest upswing of this project, coming into existence. Unfortunately, this network was not transformed successfully in the post-1989 period and began to disintegrate. To a certain extent, it has been replaced by outreach social services and drop-in centres, but the great gap this left in the medical service component remains an area of concern even today; the availability of outpatient health services for people with addictions is very limited.

\section{Building a National Infrastructure of Service Providers}

It is beyond doubt that the innovative approaches fostered by Konařík and his co-workers* helped change the ways in which the professional (especially medical) community perceived alcohol-related problems and its attitudes towards addicts and their treatment. They focused on addressing addiction in a comprehensive manner. Thus, besides addiction treatment itself, they placed an emphasis on patients' abilities to lead an independent, full-fledged alcohol-free life. They found it sensible to promote mutual support among the patients, as well as providing support for their relatives and the community. Their therapeutic approach, represented primarily by the treatment facilities in Velké Kunčice and Tuchlov, was based on help to the ill and mutual trust. This concept contributed to the creation of the necessary foundations for the bio-psycho-socio-spiritual approach to addiction treatment as we apply it today. In other words, the Cross Association and the establishment of the two treatment facilities provided the basis for a good, systematic, and therapy-oriented approach to individuals with alcohol dependency. Undoubtedly, Jaroslav Skála and his colleagues had somebody and something to follow up on and, to a certain degree (although to a surprisingly limited extent), they acknowledged this legacy (21) in their efforts, which evolved into what is now referred to as "the Apolinar addiction treatment model" (19).

The year 1957 marks another historical milestone as regards specialized addiction treatment services for children and adoles-

\footnotetext{
*Naturally, Konařík was not the only one concerned with alcohol treatment and the temperance movement and thus preparing the ground for future progress in the field. Other such personalities included Jan Šimsa (1865-1945), Gustav Kabrhel (1857-1939), Břetislav Foustka (1862-1947), and Ferdinand Pantůček (1863-1925).
} 
cents. In that year, a child psychiatrist, Jan Mečír (1925-2009), founded what was probably the very first specialized service of its kind for children and adolescents in what is now the Czech Republic (22). In 1971, this process was also reflected in the establishment of the Drug Addiction Centre situated on the premises of what is today the Substitution Treatment Centre of the Department of Addictology of the First Faculty of Medicine of Charles University and the General University Hospital in Prague. Both clinical practice and education in the field of addiction in the Czech Republic rest on solid foundations that were already laid in the 1950s. This tradition was established by Jaroslav Skála, who is still considered a major figure in Czech addiction treatment and research. In what was then Czechoslovakia, similarly to other countries around the world, addictions were a domain of psychiatry, and accordingly, it was mostly medical doctors who pursued the discipline. In addition to doctors, the roots of education also focused on paramedical professionals, particularly from 1967, when a unique form of self-experience-based education was introduced (23). The aim was to create a pool of specialists who would initiate and develop a network of services for people in what later became the Czech Republic who used (predominantly illegal) drugs. The healthcare profession of an addictologist can never substitute for a medical specialization in addictions; it is the pivotal element of the whole system of services (24).

The Velvet Revolution and the achievement of national autonomy in 1989 was a major turning point in the history of what is now the Czech Republic and brought several important changes in the field of addiction services. The existing healthcare system, particularly the network of outpatient services, was no longer efficient and difficult to reform. At the same time, the harm reduction approach was gaining traction (25), and in many ways was diametrically opposed to the existing philosophies and approaches to addiction services, which were based on abstinence-oriented approaches (ones that focused primarily on persons exhibiting alcohol dependence) (26). As new services and organizations emerged, the demands placed on addiction professionals and organizations providing addiction services increased.

In the past, persons with a wide variety of experience and training provided addiction services in the Czech Republic, ranging from lay persons and ex-users to those with academic degrees and advanced training. As a result, the lack of professional competencies and specializations in addiction emerged as an area of concern. The first educational programmes for both healthcare and social work professionals were created through collaboration between non-governmental organizations providing addiction services, healthcare institutions, and the national Drug Policy Commission. These initiatives eventually led to the development of formal academic training programmes in addictology. The process of creating the first historical policy document involved describing different types of service providers specializing in addictions and developing a network of these providers at the national level. This document (27) was developed through collaboration between both key professional national addiction societies (Society for Addiction Medicine and Czech Society of Addictologists) and after eight years (2007-2013) it was officially approved by the executive boards of these societies and then submitted to the National Drug Commission.

\section{Establishing a Real Labour Market and Workforce in Addic-} tions and Emerging Specialized Professional Societies

On the basis of a government resolution in September 1958 concerning measures to address alcohol misuse, an anti-alcohol body (Section for the Issues of Alcoholism and Other Toxicomanias) was co-founded by Jaroslav Skála later the same year. The main purpose of the Section was to bring together alcohol treatment practitioners, particularly physicians, psychologists, and social work and health professionals. The activities of the Section included disseminating information, training, and coordinating various initiatives. In addition, the Section was designed to help articulate and fulfil various tasks assigned to the Psychiatric Society, based on the national policy established in 1956, which was designed to scale up efforts to address alcoholism. At the outset, Skála (28) was committed to recruiting new professionals for the emerging specialized facilities, drawing up guidelines for alcohol treatment (e.g. differentiation of alcohol treatment facilities,) organizing alcoholism research, and developing and maintaining international cooperation. The first working meeting of the Section took place in Prague in December 1958.

The critical movement in modern history was the establishment (in 1993) of the highly prestigious interdisciplinary Society for Addiction Medicine (SNN), which represents all kinds of professionals (medical, paramedical, social, etc.) and has assumed a leading role in the field. This Society is part of the J. E. Purkyně Czech Medical Association. The establishment of this society was a symbolic act in terms of creating equality between addiction professionals with different original backgrounds and creating a uniform and sustainable framework for the entire addiction field.

One of the key infrastructural developments in the Czech Republic was a professional association that brought together addiction professionals and advocates of their interests. The Czech Association of Addictologists (CAA) was established in 2009. It is a registered (legally recognized) body consisting of members, an executive committee, a chair and two deputy chairs, an audit committee, and specific professional sections. In general, its main goals are to increase the quality and stability of the profession and to communicate with relevant stakeholders to enhance addiction services and training. According to the CAA statutes (29), the main purpose of the organization is to communicate and achieve common goals not only among addiction specialists, but among all professionals working in the addiction field. This is important for the strategic coordination of all the entities involved, and it has helped support the development of an autonomous discipline of addictology. The CAA has been active in education and training, developing the system of addiction services, negotiating with various stakeholder institutions, empowering addiction professionals, increasing the recognition of non-medical healthcare workers in the system, and preparing legislation.

One of the key issues in the Czech Republic related to addiction services has been the lack of adequate funding. Thanks in part to the advocacy of the CAA, since 2014 (Decree No. 421/2013, Coll.) the Czech Republic has benefited from addiction-specific healthcare operations (30) that are anchored in legislation, which make it possible for addiction specialists to receive insurance reimbursement for their services. Another outcome of the CAA's activities is progress in developing education programmes for addiction specialists, including the development of a specialist degree programme (clinical addictologist), which again broadens 
the options for financial support and types of services that addiction specialists can legally provide (31).

In 2015, the Czech Association of Students of Addictology (CASA) (32) was established to complement the Czech Association of Addictologists (CAA), and was dedicated to establishing a network of students in university-based addiction studies programmes (bachelor's, master's and Ph.D.). Many activities are being developed and managed by this student organization, such as public presentations and publicizing activities from the addiction field and conducted by addiction professionals, highlighting available addiction study programmes, providing seminars for students to interact with important addiction professionals and scholars, and the development of international exchange programmes between universities. In 2016, following the creation of the CAA, the Czech Society for Prevention Professionals (OSPRCH) was established as a national partner and counterpart of the European Society of Prevention Research Professionals (EUSPR). This national organization is specifically dedicated to prevention science and practice in addiction prevention and the prevention of risk behaviours related to substance misuse. Two other organizations in the Czech Republic are worth noting; one is the Association of Non-Governmental Drug Service Providers (A.N.O.), established in 1995 to support drug prevention and treatment services provided by private providers. A second organization, named "RECOVERY", was established in 2018, and aims to promote patients' rights and provide advocacy in the areas of prevention, treatment, and rehabilitation in the area of addictions. The RECOVERY organization follows the historical precedent of self-help activities and recovery activities established in the Czech Republic (16).

\section{Building the First and Unique Identity of the Addiction Field: Professional Bulletins and Journals and Establishing an Ad- diction Library}

In 1949, the bulletin Zápisy z Apolináre was founded. This bulletin was shared by professionals and patients and had many different functions, from supporting motivation to sharing general information (educational function), etc. The bulletin was developed and distributed by the staff and patients of the Apolinar facility.

The first specialized professional addiction journal in Czechoslovakia (shared by Czech and Slovak professionals) Protialkoholni obzor was developed in 1963, and is one of the oldest addiction journals in Europe (1). The Journal was renamed Alkoholismus a drogové závislosti after the Velvet Revolution in 1989, and after the split of Czechoslovakia was based in Bratislava as a Slovak national addiction journal. Because of this separation, the Czech Republic lost its only national professional addiction journal. After several years, discussions in professional societies led to the creation of a working group, which, in 2001, established a new national Czech professional journal Adiktologie (3). In 2003 the journal became a member of the International Society of Addiction Journal Editors (ISAJE), and in 2016 was completely transformed into an international open-access English-language journal. The Adiktologie journal dealt all the time with balancing between a research/scientific focus and a practically-oriented focus. There was a very clear need expressed at many annual addiction conferences to have a very practically-oriented platform for sharing clinical experience. This competitive situation was solved by two decisions. The first step was establishing a national bulletin, Zaostřeno na drogy in 2004 according to an international concept developed and published by the EMCDDA, "Drugs in Focus". The Czech national version is operated by the National Drug Commission and National Focal Point, based at the Governmental Office in Prague. The second step was the establishment of a national version of the Addictology Journal named Adiktologie pro preventivni a léčebnou praxi in 2016. Both versions of the journal are operated and published by a small NGO publishing company, SCAN.

\section{Specialized Addiction Training and Educational Programmes and Academic Infrastructure}

Together with Jaroslav Rubeš and Eduard Urban, Skála founded SUR, a dynamically oriented model of training in psychotherapy based on group and community approaches - with a special focus on addiction issues and staff working in special addiction facilities. Between 1968 and 1997, he founded or co-founded a total of 20 self-experience training communities (involving 50 groups numbering over 500 participants and 50 pair therapists). In addition to ethical issues concerning attitudes towards addicts, another important aspect which the Apolinar model accentuated was the issue of the dignity of their lives (33).

After the revolutionary year of 1989 in Czechoslovakia, a need for the proper education of people working in the addiction field emerged. As previously mentioned, the role of NGOs was crucial in providing training programmes (34). As discussion ensued, the Centre for Addictology of the Psychiatric Department of the First Faculty of Medicine of Charles University was established as a research and educational centre in 2004. In 2005, a bachelor's degree study programme in addictology was established as a specialization in the healthcare academic programme, followed in 2010 by a master's degree study programme (3). In 2012, a Ph.D. programme was launched and the Centre merged with the Addiction Treatment Department of the General University Hospital, giving rise to today's independent Department of Addictology of the First Faculty of Medicine of Charles University and General University Hospital in Prague. This process was supported by the relevant professional organizations, the Society for Addictive Diseases and the Czech Association of Addictologists (13). The model of academic education in addictions, called "the comprehensive Prague model of addiction studies" (6), was included in national legislation, with addictology established as a paramedical regulated health profession. As a result, people who graduated from this academic programme represent a new generation of highly trained professionals with competences that are aligned with real-world needs in the areas of addiction prevention, treatment, recovery, and harm reduction $(35,36)$, or more general reflections of this process (4). In 2012, the first specialized addiction library was established in the Department of Addictology.

A critical challenge for the Czech national education and training system related to addictology was managing postgraduate training and education, including continuing education for addiction professionals. Although many such activities were initiated by active and progressive NGOs such as SANANIM in Prague and Společnost Podané ruce in Brno, grounding these activities within the Czech national legislation and achieving acceptance of these education/training activities by governmental agencies 
and local authorities represented a major challenge. An important step was the establishment of the Sub-department for Addictive Diseases of the Institute for Postgraduate Medical Education in 1998, which educates and trains physicians with specializations in all clinical branches and also pharmacists. This Institute had a significant impact on developing the entire health education system in the Czech Republic, and now plays a critical role in coordinating ongoing discussion and defining the parameters of the education and training system for health professionals in the Czech Republic and standards for professional services. In collaboration with professional societies, Charles University has systematically grounded Czech addiction training and education programmes under the umbrella of this institute, and as a result has achieved acceptance from all the relevant stakeholders, including governmental ministries and health insurance companies. Several important education and training programmes have also been implemented, including specialized training for all medical doctors participating in clinical internships in the Czech Republic and specialized training for nurses and pharmacy professionals. Following the reorganization of the Sub-department in 2018, the first historical national policy document was developed for education and training in addiction studies, which included discussion of the system of addiction services and planned steps to improve the system (26).

Establishing academic training programmes in addictology was accompanied by a growth of research and evaluation activities. This trend had its historical roots in a tradition established by the Psychiatric Centre in Prague (PCP), which led to the creation of a specialized and robust research programme at the National Institute of Mental Health (NUDZ). This research began in the 1950s and 1960s in the former Czechoslovakia (37). Very similar processes led to the establishment of the Department of Addictology at the First Faculty of Medicine of Charles University. Simultaneously with these activities, the National Focal Point was established as part of the REITOX network, managed by the EMCDDA. This governmental department sponsors many research and evaluation activities and represents a natural partner of NUDZ and Charles University. These three institutions represent the leadership of modern interdisciplinary-based addiction research in the Czech Republic (38), and are responsible for the emergence of innovative research programmes in biomedicine.

\section{DISCUSSION}

As the need for highly trained addiction specialists grows throughout the world, the emergence of integrated addiction study programmes at Charles University in the Czech Republic and other similar programmes may be instructive for other universities in implementing advanced academic training. An insight into the national process and its logic is essential for a better understanding of the latest developments at the global level. This, and other case studies from different countries, may help to facilitate the development of these academic programmes and to provide an understanding of the cultural, historical, and economic contexts in which these integrated academic programmes were established. For example, it would be useful to benefit from these case studies in identifying conditions and factors that accelerate or hamper this process of developing multi-tiered academic programmes in addiction studies.
Specialized services in addiction counselling that emerged more than 30 years ago have become the subject of criticism because of the lack of comprehensive and standardized training. The counsellors themselves were able to influence the form of this specialization, and yet there were no rules for education and the profession was not integrated into the current care system. The development of a new profession was facilitated by the healthcare crisis created by drug use and the spread of HIV in the 1980s. Various services were established in response to the multiple harms associated with substance use.

The first proposal for an addiction counselling specialization becoming a part of the healthcare system was presented at the Irish National Council on Alcoholism, and in 1977 the Alcoholism Counsellors' Training Programme was opened (39). Since 1984 a Diploma in Addiction Studies has been offered by Trinity College, Dublin. In 1998 the Diploma was extended to feature a separate Master of Science in Drug and Alcohol Policy programme (40). One of the key principles in launching new study programmes and the new profession is support from the relevant ministries. In 1990 the Irish Association of Alcohol and Addiction Counsellors came into existence, which was a major step in the whole process of developing the new profession. The Association is responsible for accreditation standards, lifelong learning, ethical rules, etc. The Health and Social Care Professionals Act of 2005 lays down a registration system for healthcare professions; the profession of an addiction counsellor was integrated in 2009 (39).

Similarly to the Czech Republic and other countries, the provision of services raises the question of practitioners' appropriate qualifications. A workforce survey carried out in New Zealand in 1998 (41) showed that only 5\% of the staff members of drug services had a postgraduate qualification in addictions, with a further $40 \%$ holding an undergraduate qualification. Another important factor is that the other professionals working in addiction services did not primarily want to work with substance users. In the mid-1990s, addiction-related topics were integrated into two existing undergraduate medical programmes. Support for an addiction workforce rose, and currently there are two specialized programmes offered at the University of Auckland and University of Otago. They were introduced as single-subject postgraduate courses in 1989 and 1995, respectively, and in 1998 there were enough financial resources to launch a full-fledged postgraduate certificate programme, titled Addiction and Co-existing Disorders. It involves half a year of full-time study (42).

Adams et al. (42) emphasized the principal conditions that must be met for a specialized academic programme in addictions to run successfully and for the relevant training and profession to be integrated into the existing systems. It should be noted at this point that the key factors in the provision of quality care are the definition of professional competencies, the establishment of mechanisms ensuring adherence to ethical rules, and collaboration between professions. The development of the practical part of the studies is important, as it encourages people to work in the field while studying. Professional and educational standards must be in place, professional platforms and key documents relevant to the field must be developed, and public awareness must be raised $(35,42)$. Last but not least, lifelong learning and an accreditation process are also vital elements.

South Africa used to have an insufficient number of health professionals who were properly trained in addictions. Other 
programmes often did not include addiction courses, and no specialized training existed until the first postgraduate qualification programmes were started at the University of Cape Town: the Postgraduate Diploma in Addictions Care and the Master of Philosophy in Addictions and Mental Health in 2011 and 2010, respectively (36). The decision to provide financial support to accredited training programmes rather than short-term unaccredited courses played a key role in the ongoing provision of these programmes; the provincial government regularly invests in the development of addiction training at the University of Cape Town. Pasche et al. (36) described some factors necessary for developing, implementing, and maintaining academic programmes in developing countries. The challenges that were identified included the lack of well-trained teachers and supervisors and students struggling with differences between the theory they learnt and the day-to-day practice, in which totally different methods were used. Of course, the key factors are stable funding for the programmes and the adoption of measures needed to ensure good clinical training for students. Unfortunately, there is no subspecialization and accreditation recognized in South Africa, which, according to Pasche et al. (36), can prevent some applicants from pursuing this type of studies.

In Kenya, there is a dearth of research and documentation on the status of addiction education in the country. Currently, the field of addiction training is relatively young, with a few certificate and diploma courses in addiction counselling on offer by some middle-level colleges. Further, there are a few universities that offer master's degrees in counselling psychology that have a few courses or a concentration on/specializations in the field of addiction counselling. Therefore, great emphasis should be placed on enriching the counselling trainees with some basic knowledge of the addiction field. There has not been a standalone programme in a university focusing on addiction studies. Recently Kenyatta University, one of the largest state universities in Kenya, became the first university offering a fully-fledged postgraduate programme in addiction studies (Postgraduate Diploma in Addiction Treatment Science). This programme adopts a new approach that recognizes the need to have addiction studies as a distinct discipline, separate from counselling psychology, and one that reflects the multidisciplinary/interdisciplinary nature of the addiction field. The programme targets those with a bachelor's degree from various related disciplines such as psychology, medicine and health sciences and social work. This is the first step which will lead to the development of a full-fledged master's degree and later Ph.D. in the field of addiction science, with the aim of developing a cadre of professionals specializing in addiction science in Kenya. This approach of beginning with a postgraduate diploma serves to attract and develop interest from related disciplines that reflect the diversity of the addiction discipline. It is hoped that this programme may become the benchmark for other universities in the country and the region towards professionalization of the field of addiction studies and the establishment of addiction studies as a recognized discipline.

Students' associations and other relevant activities that support students and early-career professionals are very important in every country and region. We need to engage and energize students. It is also good to express and make clear what their active role can be and why this partnership should be created. It is about inviting students into the creative process to bring new ideas, energy and motivation, etc. Students can invest time and energy into our joint hard work through activities such as e.g. internal evaluation, peer-to-peer feedback, and support, and they can work on projects through their diploma theses. Students can also bring new ideas and initiate new ERASMUS or SOCRATES contacts (international exchange programmes for students and teachers) and help with managing them. They can refresh and contribute to our internal training and education activities and can improve the team spirit and atmosphere, etc.

In some countries we can find highly sophisticated models for the regulation of the national labour market in the addiction field and the use of national regulations on different levels, bringing together different national and local authorities for national licensing and credential procedures and covering all kinds of professions working in specialized drug services (38) and based on principles and minimum standards that are defined and required for all professionals. These formal acts provide more regulatory features and make the labour market more structured and better regulated. From another perspective, this approach needs a relatively well-structured labour market with a sufficient number of real jobs and active participation by professional societies and service providers/employers. It represents a very effective tool with a direct impact on the quality of the workforce and the services provided.

The importance of the national infrastructures is clear, and yet there is also a question of connecting what is functioning, sharing experience, exchanging information and thus developing the international structures and network of organizations (43). We can see the attempts, for example, at establishing associations of universities providing education in addictions around the world (ICUDDR) or the society of addiction professionals (ISSUP); these two platforms cooperate, prepare conferences together, and share the trends in the field. Each country's network in the addiction field should try to overcome the gap between what they do and how they do it abroad. Hand in hand, this process strengthens the identity and professionalization of the whole addiction field.

\section{CONCLUSION}

The global process of establishing the first addiction-specific institutions dedicated to research and education had its preliminary source and prototype at the national level in the Czech Republic, Ireland and New Zealand. This made it possible to further develop a distinctive career path in addiction services (e.g. prevention and treatment) and to create a comprehensive national infrastructure to address the needs for workforce development and addiction research. Real career opportunities (2) created by job market demands in many countries have also created the momentum to develop academic centres for addiction specialists and professionals. Human resources are crucial for treatment and prevention services, as well as for science and research, in all aspects of behavioural health services, including the addictions field. As demonstrated in the Czech Republic and several other countries, the creation of successful and sustainable specialized academic study programmes in addiction studies is dependent on the infrastructure provided at the national (and international) level, which has helped to shape the emergence of a more diverse and skilled workforce of addiction practitioners and researchers. 


\section{Conflict of Interests}

None declared

\section{Grant Support}

Institutional support was provided by Charles University, Progress Programme No. Q06/LF1, Grant INL/Colombo Plan, and ICUDDR.

\section{REFERENCES}

1. Babor TF, Morisano D, Noel J, Robaina K, Ward JH, Mitchell AL. Infrastructure and career opportunities in addiction science: the emergence of an interdisciplinary field. In: Babor TF, Stenius K, Pates R, Miovský M, O'Reilly J, Candon P, editors. Publishing addiction science: a guide for the perplexed. London: Ubiquity Press; 2017. p. 9-34.

2. Edwards G, editor. Addiction: evolution of a specialist field. Oxford: Blackwell Science; 2002.

3. Miovský M, Miller P, Grund JP, Belackova V, Gabrhelik R, Libra J. Academic education in addictology (addiction science) in the Czech Republic: analysis of the (pre-1989) historical origins. Nordisk Alkohol Nark. 2015;32(5):527-38.

4. Thom B, Duke K, Herring R. Workforce development: Is there a paradigm shift? Drugs (Abingdon Engl). 2017;24(6):427-9.

5. Pavlovská A, Miovský M, Babor TF, Gabrhelík R. Overview of the European university-based study programmes in the addictions field. Drugs (Abingdon Engl). 2017;24(6):485-91.

6. Pavlovská A, Peters RH, Gabrhelík R, Miovský M, Sloboda Z, Babor TF. Overview of the university-based addiction studies programmes in the United States. J Subst Use. 2019;24(1):55-60.

7. Yin RK. Case study research: design and methods. Thousand Oaks: SAGE Publications; 1989.

8. Glaser BG, Strauss AL. The discovery of grounded theory: strategies for qualitative research. London: Aldine; 1967.

9. Strauss AL, Corbin JM, editors. Grounded theory in practice. Thousand Oaks: SAGE Publications; 1997.

10. Miles MB, Huberman AM. Qualitative data analysis: an expanded sourcebook. Thousand Oaks: SAGE Publications; 1994.

11. Denzin NK, Lincoln YS, editors. Collecting and interpreting qualitative materials. Thousand Oaks: SAGE Publications; 1998.

12. Miovsky M, Gabrhelík R, Libra J, Popov P, Pavlovska A, Kalina K, et al. The Prague comprehensive model of academic addictology (addiction science) education. Adiktologie. 2016;16(1):36-49.

13. Písecký F. Teetotalism at secondary schools. Ostř́ízlivění. 1912-13. (In Czech)

14. Foerster V. Youth, spirits, character. Ostřízlivění. 1912-13. (In Czech)

15. Mikotová M. Fifty years of the alcohol counselling service in Brno. Protialkoholický obzor. 1981;16(6):365-9. (In Czech.)

16. Gabrhelík R, Miovský M. History of self-help and 'quasi-self-help' groups in the Czech Republic: development and current situation in the institutional context of drug services. Adiktologie. 2011;11(2):101-12.

17. Miovský M, Popov P, Šejvl J. The "U Apolináŕe" Department of Addictology from the perspective of the 70 years of its development. Prague: The Department of Addictology, First Faculty of Medicine, Charles University and General University Hospital in Prague; 2018. (In Czech.)

18. Larkin T. Users Forum as an advisory board for the government. UISCE as an organization, its significance for users and society. In: 9th National Conference of the Society of Addictive Diseases and 42nd Conference of the Jan Evangelista Purkyne Czech Medical Association; 2003 May 19-23; Měřín, Czech Republic. Tišnov: Sdružení SCAN; 2003.

19. Šejvl J, Miovský M. The First specialised residential treatment institution and programme for alcohol-related problems in the historical area of Bohemia and Moravia: case study of the first residential alcohol programme in Velké Kunčice (1911-1915). Adiktologie. 2017;17(2):134-46. (In Czech.)

20. Šejvl J, Miovský M. The First facility for the institutional treatment of alcohol dependence in the Czechoslovak Republic: case study of the
Tuchlov treatment facility (1923-1938). Adiktol Prevent Leceb Praxi. 2018;1(2):68-78. (In Czech.)

21. Skála J. Alcoholism - terminology, diagnosis, treatment, and prevention. Prague: SZN; 1957. (In Czech.)

22. Mečír J. The Abuse of alcohol and non-alcohol drugs among young people. Prague: Avicentrum; 1989. (In Czech.)

23. Radimecký J. Lifelong education in addictology. Adiktologie. 2007;7(2):46-57. (In Czech.)

24. Polydorou S, Gunderson EW, Levin FR. Training physicians to treat substance use disorders. Curr Psychiatry Rep. 2008;10(5):399-404.

25. Janíková B. Harm reduction: early interventions in low-threshold services. In: Kalina K, et al. Basics of clinical addictology. Prague: Grada Publishing; 2008. p. 99-109. (In Czech.)

26. Miovsky M, Kalina K, Libra J. Education in addictology in the Czech Republic: the scope and role of the proposed system. Adiktologie. 2014;14(3):310-28. (In Czech.)

27. Miovský M, editor. The System of specialised addiction treatment services: a policy document. Prague: The Department of Addictology, First Faculty of Medicine, Charles University and General University Hospital in Prague; 2014. (In Czech.)

28. Skála J. A History of the Centre for Alcoholism and Other Toxicomanias (1956-1981). Protialkoholický obzor. 1984;19(4):247-9. (In Czech.)

29. Czech Association of Addictology. Articles of Association [Internet] Prague: Czech Association of Addictology; 2016 [cited 2017 Jul 20]. Available from: http://www.asociace-adiktologu.cz/wp-content/uploads/2010/02/1_stanovy_CAA_final.doc.pdf.

30. Sklenář O: 919 - Health interventions of an addictologist. Adiktologie. 2013;13(1):4-5. (In Czech.)

31. Vondrová A, Oktábec Z, Janouškovec V, Sklenář O. One stop on the way to becoming a clinical addictologist. Adiktol Prevent Leceb Praxi. 2018;1(1):39-41. (In Czech.)

32. Czech Association of Addictology Students. Articles of Association [Internet]. Prague: Czech Association of Addictology Students; 2015 [cited 2019 Nov 30]. Available from: http://www.addictology.net/o-nas/ stanovy/. (In Czech.)

33. Skála J. Ethical issues of alcohol and drug services. Zdravotnická výchova. 1985;21(2):151-6. (In Czech.)

34. Miovský M. The Health discipline of addictology: reflections on the origin, recent developments, and future orientation of the specialized academic programme. Adiktologie. 2007;7(2):30-45. (In Czech.)

35. Greer PM, Kuehn D. National education standards vital for addiction professionals. Alcohol Drug Abuse Wkly. 2009;21(18):5.

36. Pasche S, Kleintjes S, Wilson D, Stein DJ, Myers B. Improving addiction care in South Africa: Development and challenges to implementing training in addictions care at the University of Cape Town. Int J Men Health Addiction. 2014;13(3):322-32.

37. Winkler P, Csemy L. Self-experimentations with psychedelics among mental health professionals: LSD in the former Czechoslovakia. J Psychoactive Drugs. 2014;46(1):11-9.

38. Miovský M, Gabrhelík R, Libra J. The draft strategy for addiction science and research in the Czech Republic. Adiktologie. 2014;14(3):294-308.

39. Butler S. Addiction counsellors in the Republic of Ireland: exploring the emergence of a new profession. Drugs (Abingdon Engl). 2011;18(4):295302 .

40. Butler S. Addiction studies at Trinity College Dublin. Drugs (Abingdon Engl). 2011;18(4):241-2.

41. Adamson S, Deering D, Schroder R, Townshend P, Ditchburn M. National telephone survey of the addiction treatment workforce. Christchurch: National Addiction Centre, University of Otago; 2009.

42. Adams PJ, Sellman D, Newcombe D, Adamson S, White S, Deering D, et al. Postgraduate alcohol and other drug practitioner training in New Zealand: significant influences. J Stud Alcohol Drugs. 2017;78(3):468-74.

43. Miovský M. Addictology in the international context. Adiktologie. 2016;16(3):196-203. (In Czech.)

Received October 1, 2019

Accepted in revised form December 6, 2019 